\title{
Encouraging Student Success through the Creation of a Math Lab
}

Thomas E. Ware, Jr.

A pressing academic topic over the last decade has been the state of mathematics education. The most telling report was the Third International Mathematics and Science Study (TIMMS) conducted by the National Center for Education Statistics. The TIMSS surveyed a half million students in 41 nations at five grade levels for mathematics and science achievement. The TIMSS report portrayed a disturbing picture for mathematics education in the United States. First, American 8th grade students rate lower than the international average in mathematics and significantly lower in higher mathematics. In terms of overall rank, the U.S. rated lower than several European and Pacific Rim nations (NCES, 1996).

Among 8th grade students in the United States, only 23\% of the students exhibited mathematics ability described as "proficient" in solving complex problems and $4 \%$ were described as "advanced," exhibiting the ability apply abstract thought to mathematics. In Alabama, these numbers were $12 \%$ and $1 \%$ respectively (NCES, 1996).

Bevill State Community College is a four-campus publicly funded community college located in west Alabama serving a seven county area from the Birmingham metropolitan area to the Mississippi state line. Enrollment for the fall of 1999 was 3,788 students across the four main campuses and three instructional sites. The Fayette campus is located in Fayette, Alabama and had a Fall 1999 enrollment of 792 students.

In light of the national and regional trends in mathematics preparation, it should not be surprising that the level of preparedness for students enrolling in Precalculus with Algebra (MTH 112) at the Fayette campus was not very high. This also meant that student success in the course was also not very high. One possible solution was to create a mathematics laboratory.

The creation of the math lab at the Fayette campus was a measure to increase the success of entry level students in the Precalculus with Algebra course. Precalculus with Algebra is a required course for almost all associate degree programs offered by the college. In the three semesters previous to the 2000 spring semester, the rate at which students achieved a "C" or better in Precalculus was 51.7\%. The percentage of students who received a grade of " $\mathrm{D}$ " or " $\mathrm{F}$ " was $25.4 \%$. Perhaps the most disturbing trend was the percentage of students who dropped the class during the course of the semester. The percentage of withdrawals, grade "W," was $28 \%$.

In order to address these trends, the math faculty and the college's tutoring program, together with the student services staff decided to coordinate their efforts by having a centralized facility to help mathematics students of all abilities. At the beginning of the

Dr. Thomas E. Ware, Jr. is the Director of Student Support Services at Bevill State Community College, Fayette, AL 
2000 spring semester, the math faculty gave Precalculus students a diagnostic test to gauge their preparedness for the course. Students who did not score at a predetermined level were required to register for the Math Lab 1, a credit hour course (MTH 080).

The Math Lab was staffed by a developmental mathematics instructor and four peer, student tutors. The Lab was open throughout the day and had evening hours. Students who were registered for MTH 080 had to sign up for at least a 1-hour tutoring session each week. The method of instruction was left to the Math Lab participants. The tutors were available for one-on-one tutoring or simply to answer questions. Self-motivated students could utilize the tutorial software to fulfil the MTH 080 course requirements.

Two factors were examined in our self-study for the Math Lab. The first was a simple comparison of the grade distribution for Precalculus before the creation of the Math Lab with the grades from the Spring semester 2000. The second factor was to report the results from a survey of students regarding the effectiveness of the Math Lab during its initial semester of operation. A Likert-type questionnaire consisting of 10 items was administered to 20 Math Lab participants during the closing weeks of the semester. Respondents indicated their level of agreement with each item presented, ranging from "strongly disagree" to "strongly agree."

The most significant difference noted in the Spring 2000 grade distribution was the decrease in the number of withdrawals expressed as a percentage of enrollment. The number of withdrawals was only 8 out of a total enrollment of 68 or $12 \%$. The second noticeable difference was the general distribution of grades. For the Spring semester, the grades assumed more of a bell-shaped curve. The number of students receiving a grade of "C" increased to $31 \%$ from the

The results of the participant survey of the Math Lab indicated a strong level of satisfaction with the services provided. A high percentage of the respondents attended the Math Lab on a regular basis (85\%) (see Table 3). An equally high number felt that the Lab was open at times convenient to their schedule (85\%) and that the tutors were knowledgeable and demonstrated a willingness to help (80\%).

\section{TABLE 3}

\section{Satisfaction Survey of Math Lab Participants, Spring 2000}

$\mathrm{n}=20$

SD \% $\quad$ D \% $\quad$ A $\% \quad$ SA $\% \quad$ M

(SD)

$\begin{array}{lcccccc}\text { Attended Math Lab regularly } & 5 & 10 & 45 & 40 & 3.20 & (0.81) \\ \begin{array}{l}\text { Math Lab open and } \\ \text { times convenient }\end{array} & 5 & 10 & 30 & 55 & 3.35 & (0.85) \\ \begin{array}{l}\text { Tutors knowledgeable and } \\ \text { Wing }\end{array} & 10 & 10 & 30 & 50 & 3.20 & (0.98)\end{array}$

willing to help 


\begin{tabular}{|c|c|c|c|c|c|c|}
\hline $\begin{array}{l}\text { Used computer } \\
\text { tutorial software }\end{array}$ & 10 & 0 & 35 & 55 & 3.35 & $(0.91)$ \\
\hline Software adequate & 5 & 0 & 55 & 40 & 3.30 & $(0.71)$ \\
\hline Facilities are adequate & 5 & 0 & 40 & 55 & 3.45 & $(0.74)$ \\
\hline $\begin{array}{l}\text { Environment is conducive to } \\
\text { learning }\end{array}$ & 5 & 0 & 55 & 40 & 3.30 & $(0.71)$ \\
\hline $\begin{array}{l}\text { Math Lab improved math } \\
\text { skills and knowledge }\end{array}$ & 5 & 5 & 50 & 40 & 3.25 & $(0.77)$ \\
\hline $\begin{array}{l}\text { Math Lab helped grade } \\
\text { in math course }\end{array}$ & 5 & 5 & 50 & 40 & 3.25 & $(0.77)$ \\
\hline $\begin{array}{l}\text { Use Math Lab in future math } \\
\text { courses }\end{array}$ & 5 & 0 & 50 & 45 & 3.35 & $(0.73)$ \\
\hline
\end{tabular}

One of the most surprising results was in the use of computer tutorial software, $90 \%$ of students using the lab, $95 \%$ felt that the software and facilities were adequate to meet their needs. According to the respondents, the learning environment of the Math Lab was conducive to learning (95\%).

The most encouraging results of the survey were perceived grade impact and confidence in math skills. Most respondents felt that the Math Lab had improved their math skills and knowledge (90\%). Also, 90\% felt that the Math Lab had helped their grade in the concurrent math course. Most of the survey participants indicated that they would utilize the Math Lab in any future mathematics course taken while at the college (95\%).

These results are too limited in scope to make any generalizations about the effectiveness of the Math Lab in Precalculus achievement. As this system is used in future semesters, a more definitive study of its effectiveness can be conducted. The value of these early results is to provide some indications that the administrators of the Math $\mathrm{Lab}$ are on the right track in finding ways to improve the success rate of Precalculus students. Also, the demonstration of effort on the part of the college's faculty and staff provides an additional area of support for new students who may have apprehensions about Precalculus, math in general, and their initial enrollment in college.

\section{References}

National Center for Educational Statistics (1996). NAEP 1996: Report Card for the Nation and the States. Washington, DC: Department of Education.

Mathematics and Science Teaching, Learning, Curriculum, and Achievement in International Context. Conclusions. (1996). Pursuing excellence: A study of U.S. eighth grade. Retrieved at http://www.ed.gov/NCES/TIMMS/97198-9.html. 